\title{
Localized Epidermal Cysts as a Radiation Recall Phenomenon in a Melanoma Patient Treated with Radiotherapy and the BRAF Inhibitor Vemurafenib
}

\author{
Carine Houriet $^{\mathrm{a}} \quad$ Natalie D. Klass ${ }^{\mathrm{b}} \quad$ Helmut Beltraminelli ${ }^{\mathrm{a}}$ \\ Luca Borradori $^{a}$ Patrick A. Oberholzer ${ }^{\mathrm{a}}$ \\ Departments of ${ }^{\mathrm{a}}$ Dermatology and ${ }^{\mathrm{b}}$ Radiotherapy, Inselspital, University of Berne, \\ Berne, Switzerland
}

\section{Key Words}

Vemurafenib · BRAF inhibitor · Epidermal cysts · Side effect · Radiotherapy · Melanoma

\begin{abstract}
BRAF inhibitors are broadly used for metastatic melanoma with BRAF mutations. Their use results in various cutaneous side effects, such as the development of keratoacanthomas and squamous cell carcinomas. We report a patient with metastatic melanoma treated with vemurafenib who developed dozens of histologically confirmed epidermal cysts within 2 months after initiation of vemurafenib administration. The cystic lesions were observed only in the localized area where a large exophytic melanoma tumor mass had been previously irradiated. Localized epidermal cysts may constitute an unusual radiation recall reaction in patients treated with BRAF inhibitors.

(C) 2014 S. Karger AG, Basel
\end{abstract}

\section{Introduction}

Vemurafenib is a BRAF inhibitor widely used as a targeted therapy in BRAF-mutated metastatic melanoma [1]. BRAF mutations are present in $40-60 \%$ of patients with cutaneous melanoma [1, 2], by far the most common mutation being V600E [1-3].

Vemurafenib therapy is associated with several cutaneous side effects, including palmoplantar erythema, UVA-induced photosensitivity, hyperkeratotic lesions of the soles, 
development of keratoacanthomas and squamous cell carcinomas as well as new primary melanomas [1-5]. Inflammatory cutaneous side effects were reported as early as 3-6 weeks after initiation of vemurafenib treatment. So far only a few reports describing radiosensitization or radiation recall dermatitis following treatment with BRAF inhibitors exist [6].

We report the development of localized epidermal cysts following radiotherapy and treatment with vemurafenib.

\section{Case Report}

A 43-year-old female patient with a recently diagnosed metastatic melanoma, AJCC stage IV, was referred for evaluation of cystic lesions on the lateral face and left neck region. These cysts had started growing during the previous 6 weeks. The patient initially presented with an $8 \times 15 \mathrm{~cm}$ exophytic pigmented tumor mass in the left inframandibular neck region. Light microscopy studies confirmed the diagnosis of melanoma, although it remained unclear whether the lesion represented a primary or a local metastasis. Staging exams including total body computed tomography showed a pelvic tumor mass $20 \mathrm{~cm}$ in diameter with diffuse enlargement of mesenteric, paraaortic and cervical lymph nodes. The lesions were regarded as lymph node metastases of the melanoma. Magnetic resonance imaging of the brain excluded the presence of brain metastases.

Because of the advanced stage of the tumor palliative, neoadjuvant, hypofractionated radiotherapy was started. The exophytic tumor in the neck was given a total radiation dose of 30 Gy with $6 \times 5$ Gy per daily fraction administered 5 days per week. Based on the detection of a BRAF mutation V600E in exon 15, the patient was given vemurafenib (Zelboraf ${ }^{\circledR}$ ) $960 \mathrm{mg}$ twice daily 3 days after completion of the radiotherapy. At the follow-up visit 3 months after radiotherapy, the patient was found to have multiple epidermal cysts in the previous irradiation field, i.e. the left temple, ear and auditory canal and posterior neck region (fig. 1). Light microscopy studies confirmed the diagnosis (fig. 2). At the 1-year follow-up visit the patient's situation was stable and the number of epidermal cysts unchanged.

\section{Discussion}

The use of BRAF inhibitors is associated with numerous cutaneous side effects. Most notably, BRAF inhibition leads to the formation of squamous cell carcinomas in RAS-primed cells due to an activation of the MAPK pathway [3,7]. Nevertheless, there are few data about the side effects related to the combined use of BRAF inhibitors and radiotherapy.

In our case, the development of cysts limited to a previously irradiated field was highly unusual and peculiar in our experience. Even though milia-like epidermal cysts have been described in patients treated with the BRAF inhibitor vemurafenib [8], in our case this phenomenon was specifically observed only in the irradiated field, suggesting that the irradiation resulted in a localized susceptibility for the side effects of vemurafenib in the context of a so-called radiosensitization or radiation recall dermatitis. Nevertheless the exact pathomechanisms responsible for a radiation recall dermatitis remain unclear. The irradiation is likely to lead to an inflammatory reaction and tissue damage related to the release of inflammatory cytokines such as TNF- $\alpha$, interleukin-1 and interleukin-6 [9]. Initiation of medicamentous therapy may again trigger a local reaction by releasing these cytokines [9]. 
Houriet et al.: Localized Epidermal Cysts as a Radiation Recall Phenomenon in a Melanoma Patient Treated with Radiotherapy and the BRAF Inhibitor Vemurafenib

Previous in vitro studies have shown that simultaneous administration of radiotherapy and sorafenib is associated with enhanced cytotoxic effects. It is conceivable that the latter is related to radiation-induced DNA damage with a higher cell count in a vulnerable phase of the cell cycle together with an additional inhibition of DNA repair by sorafenib [10]. Another in vitro model provided evidence that BRAF-positive melanoma cells are radiosensitized following BRAF inhibition [11]. In our case, the formation of cystic lesions may be dependent on RAS activation [3], as reported for keratoacanthomas and squamous cell carcinoma.

Only a few similar cases of localized skin reactions in irradiated areas following BRAF inhibition have been described so far. In one other case report cystic lesions were observed [12]. Boussemart et al. $[8,13]$ reported two cases of pruriginous skin reactions. Ducassou et al. [9] and Satzger et al. [6] reported cases of an asymptomatic erythematous reaction limited to the irradiated area, an observation suggesting a cutaneous radiosensitization related to vemurafenib. Also some cases of severe radiotherapy-induced visceral toxicity were observed $[14,15]$.

Recently, an increasing number of both cutaneous and visceral radiation recall reactions have been reported following the administration of BRAF inhibitors. Since little is known about the pathogenesis of these side effect conditions, further research in the growing field of combined kinase inhibitor treatment with or without radiation has to be undertaken.

\section{Disclosure Statement}

The authors have no conflict of interest.

\section{References}

1 McArthur GA, Chapman PB, Robert C, Larkin J, Haanen JB, Dummer R, Ribas A, Hogg D, Hamid O, Ascierto PA, Garbe C, Testori A, Maio M, Lorigan P, Lebbé C, Jouary T, Schadendorf D, O’Day SJ, Kirkwood JM, Eggermont AM, Dréno B, Sosman JA, Flaherty KT, Yin M, Caro I, Cheng S, Trunzer K, Hauschild A: Safety and efficacy of vemurafenib in BRAF(V600E) and BRAF(V600K) mutation-positive melanoma (BRIM-3): extended follow-up of a phase 3, randomised, open-label study. Lancet Oncol 2014;15:323-332.

-2 Anforth RM, Blumetti TC, Kefford RF, Sharma R, Scolyer RA, Kossard S, Long GV, Fernandez-Penas P: Cutaneous manifestations of dabrafenib (GSK2118436): a selective inhibitor of mutant BRAF in patients with metastatic melanoma. Br J Dermatol 2012;167:1153-1160.

-3 Rinderknecht JD, Goldinger SM, Rozati S, Kamarashev J, Kerl K, French LE, Dummer R, Belloni B: RASopathic skin eruptions during vemurafenib therapy. PLoS One 2013;8:e58721.

4 Bollag G, Hirth P, Tsai J, Zhang J, Ibrahim PN, Cho H, Spevak W, Zhang C, Zhang Y, Habets G, Burton EA, Wong B, Tsang G, West BL, Powell B, Shellooe R, Marimuthu A, Nguyen H, Zhang KY, Artis DR, Schlessinger J, Su F, Higgins B, Iyer R, D’Andrea K, Koehler A, Stumm M, Lin PS, Lee RJ, Grippo J, Puzanov I, Kim KB, Ribas A, McArthur GA, Sosman JA, Chapman PB, Flaherty KT, Xu X, Nathanson KL, Nolop K: Clinical efficacy of a RAF inhibitor needs broad target blockade in BRAF-mutant melanoma. Nature 2010;467:596-599.

5 Dummer R, Rinderknecht J, Goldinger SM: Ultraviolet A and photosensitivity during vemurafenib therapy. N Engl J Med 2012;366:480-481.

6 Satzger I, Degen A, Asper H, Kapp A, Hauschild A, Gutzmer R: Serious skin toxicity with the combination of BRAF inhibitors and radiotherapy. J Clin Oncol 2013;31:e220-e222.

7 Oberholzer PA, Kee D, Dziunycz P, Sucker A, Kamsukom N, Jones R, Roden C, Chalk CJ, Ardlie K, Palescandolo E, Piris A, Macconaill LE, Robert C, Hofbauer GF, McArthur GA, Schadendorf D, Garraway LA: RAS mutations are associated with the development of cutaneous squamous cell tumors in patients treated with RAF inhibitors. J Clin Oncol 2012;30:316-321.

-8 Boussemart L, Routier E, Mateus C, Opletalova K, Sebille G, Kamsu-Kom N, Thomas M, Vagner S, Favre M, Tomasic G, Wechsler J, Lacroix L, Robert C: Prospective study of cutaneous side-effects associated with the BRAF inhibitor vemurafenib: a study of 42 patients. Ann Oncol 2013;24:1691-1697.

\9 Ducassou A, David I, Delannes M, Chevreau C, Sibaud V: Radiosensitization induced by vemurafenib (in French). Cancer Radiother 2013;17:304-307. 
Houriet et al.: Localized Epidermal Cysts as a Radiation Recall Phenomenon in a Melanoma Patient Treated with Radiotherapy and the BRAF Inhibitor Vemurafenib

10 Kim YB, Jeung HC, Jeong I, Lee K, Rha SY, Chung HC, Kim GE: Mechanism of enhancement of radiationinduced cytotoxicity by sorafenib in colorectal cancer. J Radiat Res 2013;54:52-60.

11 Sambade MJ, Peters EC, Thomas NE, Kaufmann WK, Kimple RJ, Shields JM: Melanoma cells show a heterogeneous range of sensitivity to ionizing radiation and are radiosensitized by inhibition of B-RAF with PLX-4032. Radiother Oncol 2011;98:394-399.

12 Schulze B, Meissner M, Wolter M, Rodel C, Weiss C: Unusual acute and delayed skin reactions during and after whole-brain radiotherapy in combination with the BRAF inhibitor vemurafenib. Two case reports. Strahlenther Onkol 2014;190:229-232.

13 Boussemart L, Boivin C, Claveau J, Tao YG, Tomasic G, Routier E, Mateus C, Deutsch E, Robert C: Vemurafenib and radiosensitization. JAMA Dermatol 2013;149:855-857.

14 Forschner A, Zips D, Schraml C, Röcken M, Iordanou E, Leiter U, Weide B, Garbe C, Meier F: Radiation recall dermatitis and radiation pneumonitis during treatment with vemurafenib. Melanoma Res 2014, Epub ahead of print.

15 Peuvrel L, Ruellan AL, Thillays F, Quereux G, Brocard A, Saint-Jean M, Aumont M, Drouet F, Dréno B: Severe radiotherapy-induced extracutaneous toxicity under vemurafenib. Eur J Dermatol 2013;23:879-881.

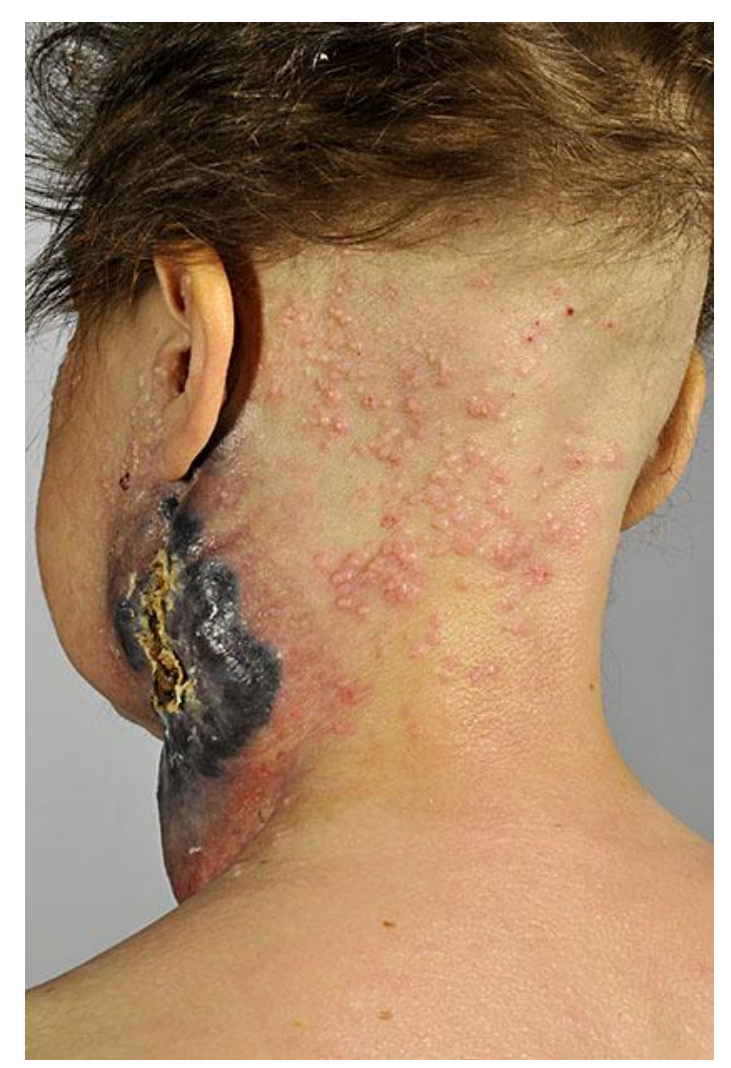

Fig. 1. Development of several epidermal cysts in the head and neck area where a large exophytic melanoma tumor mass had been previously irradiated. 
Houriet et al.: Localized Epidermal Cysts as a Radiation Recall Phenomenon in a Melanoma Patient Treated with Radiotherapy and the BRAF Inhibitor Vemurafenib
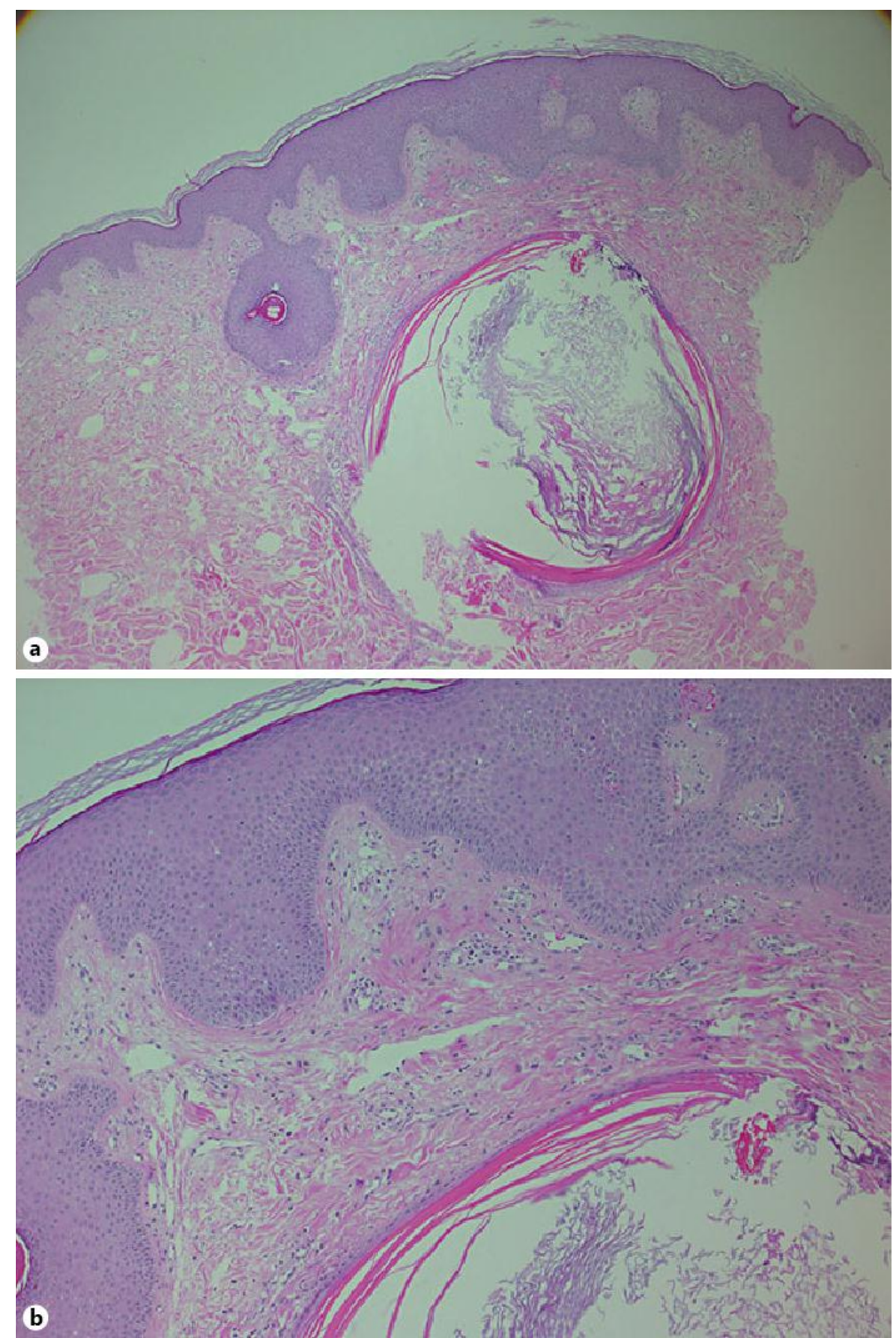

Fig. 2. Light microscopy study overview (a) and close-up view (b) of a H\&E-stained section of an excised epidermal cyst. 